\title{
AN INTERNAL MARKET FOR SERVICES - NATIONAL CONCERNS, EUROPEAN REGULATION, AND A PROPOSAL BY THE COMMISSION
}

\author{
Veith Mehde*
}

Summary: The article analyses the difficulties in creating an internal market for services with special regard to the accession of the new Member States. Starting from the example of job losses in Germany that are blamed on the application of the freedom to provide services to the new Member States, the article goes on to describe the Commission's proposal for a new directive on services in the internal market. The decision to withdraw the proposal in its original form is explained. Possible restrictions of the freedom are analysed with regard to the requirements which the ECJ has derived from the Treaty. On the basis of this case-law, fears of a 'race to the bottom' are analysed and regulatory options are assessed. It is concluded that the principle of mutual recognition has to be the basis of any solid attempt to create a functioning internal market also for services. Nevertheless, the fears existing in the old Member States - although at least partly unfounded - need to be taken seriously. Some form of harmonisation might be the price to be paid for making borders within the EU permeable to services.

\section{Introduction}

From the moment the Eastern enlargement of the EU became a realistic perspective, the preservation of social standards has been a concern in the old Member States. In many of these countries, social standards are high and the welfare state might even form an important element of the collective national identity. Consequently, the accession of states that have much lower standards has been regarded not only as a great chance and a historical obligation, but also as a significant risk. These concerns lead to the problematic restrictions on the free movement of workers and the freedom to provide services that Germany, for example, has opted for in the process of negotiating the terms of accession ${ }^{1}$. In political discussions, these restrictions have frequently been brought into play in order to respond to fears that Germany might literally be swamped by people prepared to work for much lower wages and at much lower social standards than German workers are accustomed to ${ }^{2}$.

In the meantime, it has become clear that these restrictions can be circumvented easily, as the restrictions regarding the freedom to provide services are far less rigid ${ }^{3}$. For that reason, all it needs is an employer who chooses not to employ workers, but to hire a service provider who then will make sure that he fulfils the same tasks as those that were originally fulfilled by formally employed workers. This service provider can produce at much lower costs, as he generally employs workers in accordance with the standards of his country of origin. Whether or not the prerequisites for applying the freedom to provide services are indeed met and in

\footnotetext{
· Veith Mehde, Privatdozent, Dr. jur., Rechtswissenschaftliche Fakultät, Universität Hamburg

${ }^{1}$ See Peter Tempel, The European Integration: A Policy toward Stability, Growth, and Employment, in: Bernard Funk/Lodovico Pizzati (ed.), Labor, Employment, and Social Policies in the EU Enlargement Process: Changing Perspectives and Policy Options (2002) Washington D.C.: The World Bank, p. 215 (217 f.).

${ }^{2}$ Arguments summarized by Carsten Nowak, EU-Osterweiterung, Personenfreizügigkeit und staatliche Schutzpflichten im Bereich der sozialen Sicherheit (2003) 101 Europäische Zeitschrift für Wirtschaftsrecht, p. 102.

${ }^{3}$ See Matthias Pechstein/Philipp Kubicki, Dienstleistungsfreiheit im Baugewerbe für polnische Handwerker (2004) 6 Europäische Zeitschrift für Wirtschaftsrecht 167 et seq.
} 
particular whether or not the provider can really be regarded as self-employed and the contractual relationship as being of temporary character are matters that are very hard to investig$a^{4} e^{4}$.The potential consequences can be observed in the German meat industry, where competition between the various companies is particularly fierce. According to press reports, 26.000 workers in slaughterhouses have lost their jobs since May $2004^{5}$. They have been substituted by staff formally employed by service providers from the new Member States. These service providers pay wages that might be common standard or even rather attractive in their country of origin. Still, according to a television report ${ }^{6}$ the living and working conditions of the people working for these companies are miserable. They have to work extremely long hours, live in poor accommodation provided by their employers, and they also seem to have problems getting their promised payment. It is obvious that these conditions produce a climate in which it is difficult to investigate the factual and legal circumstances of these business relationships and to expose illegal practices. Above all, questions arise as to whether the service provider really is established in another Member State and whether the activities in the host country are of a temporary character ${ }^{7}$ and whether the requirements set out in the Directive 96/71/EC concerning the posting of workers ${ }^{8}$ are met. In fact, some of the effects that now seem to be evidence of negative effects on the German job-market might well be due to a lack of application of existing rules rather than a reflection of the scope of the liberalisation instigated by these rules ${ }^{9}$.

Nevertheless, it is obvious that, under these circumstances, the freedom to provide services at least in Germany - is experienced as causing just the situation that the government has tried to avoid by delaying the application of the freedom of workers in the new Member States. Unsurprisingly, the plans of the Commission for a new directive on services in the internal market have provoked additional concerns. Politically, this was not necessarily to be expected since the secretary of state for economy and employment, Wolfgang Clement, had expressed on various occasions that the new directive would be a great chance, as it could provide a political incentive to reform outdated structures regarding the German service sector ${ }^{10}$. Nevertheless, the majority of the government ${ }^{11}$ now seems to regard this 'window of opportunity' as offering little more than the prospect of competition Germany and the German government have little chances of winning: a race to the bottom in the category 'wages' and 'social standards'. Additionally, politicians from the left in France and Germany have linked the cause to an 'ultra-liberal Europe' and have equated the new directive to 'the destruction of the European social model' 12 .

\section{A new directive on services - the proposal of the Commission}

In contrast to the concerns described in the introductory remarks, the proposal for the new directive on services in the internal market that the Commission presented in March 2004 is based on a much more optimistic view, namely its job-creating potential. The expectation regarding the significant potential for job growth is substantiated by an analysis presented to the

\footnotetext{
${ }^{4}$ Frankfurter Allgemeine Zeitung, No. 44, 22.2.2005, p. 13.

${ }^{5}$ Der Spiegel No. 7, 14.2.2005, p. 32 et seq.; Hamburger Abendblatt , 21.3.2005, p. 5.

${ }^{6}$ ARD program "report Baden-Baden", 28.2.2005.

${ }^{7}$ See Case C-215/01, Bruno Schnitzer, [2003] para. 26 et seq.

${ }^{8}$ Directive $96 / 71 /$ EC of the European Parliament and of the Council of 16 December 1996 concerning the posting of workers in the framework of the provision of services [1997] Official Journal L 018, p.1 - 6 .

${ }^{9}$ See for example interview with Commissioner Verheugen, Der Spiegel, No. 10/2005, 7.3.2005, p. 30.

${ }^{10}$ See quote in Der Spiegel No. 7, 14.2.2005, p. 35; see also The Economist, 12.3.2005, p. 36.

${ }^{11}$ The lack of unanimity in the government has been criticised by the opposition; see Frankfurter Allgemeine Zeitung, No. 40, 1.2.2005, p. 14.

${ }^{12}$ The Economist, 12/3/2005, p. 36.
} 
Commission in which the authors of 'Copenhagen Economics' predict that net employment across the EU could increase by up to 600.000 jobs $^{13}$. The argument is based on the analysis that today services already generate about $70 \%$ of GNP as well as many jobs, but that the growth potential is not exploited to the full because of the restrictions preventing the provision of services across borders ${ }^{14}$. The Commission listed these restrictions in a report on 'The State of the Internal Market for Services' in $2002^{15}$. The plan to eliminate these obstacles dates back to the Lisbon European Council of March 2000, where it was seen as one of the things that had to be done in order to make the EU the most competitive and dynamic knowledge-based economy in the world by the year $2010^{16}$. As one prerequisite to achieve this aim, the Commission suggested that services should move between the Member States as easily as within them ${ }^{17}$.

In the proposed directive, the Commission seeks to remove these barriers for all kinds of services with only few exceptions. The approach is based on the idea of a framework directive which is not meant to lead to complete harmonisation of standards, but rather attempts to tackle the obstacles in a way that leaves the specific features of the Member States' legal orders unaltered ${ }^{18}$. Three elements are characteristic of this approach: the country of origin principle, the obligation of mutual assistance between national authorities, and other regulative instruments such as harmonisation and exceptions from the country of origin principle if this is in the general interest. Of these approaches, the country of origin principle is the one which is regarded as the cause of the negative effects which national politicians are trying to prevent ${ }^{19}$. According to this principle, service providers are subject only to the law of the Member State in which they are established, so that in principle the host country is not allowed to cause any restrictions by additional regulations ${ }^{20}$. The second aspect refers to the administrative monitoring of service providers.

Even when the law is not itself the reason for obstacles, the administration of the country in which the service is provided might apply it in a way that in itself causes an obstruction. Therefore, the Commission proposes to force the Member States to introduce 'single points of contact' $^{21}$. According to this concept, service providers have a right to deal with only one administrative body through which they can handle all formalities and all procedures relevant for their activity. Additionally, even non-discriminatory authorisation schemes that might limit the access to markets in the respective Member State are generally prohibited as long as they are not justified by 'an overriding reason relating to the public interest' and less restrictive measures would not be sufficient to pursue the objective ${ }^{22}$. As far as the topic of harmonisation is concerned, the Commission only hints that there might be a need for additional initiatives in the field of consumer protection and whenever the functioning of the internal market requires common standards ${ }^{23}$.

\footnotetext{
${ }^{13}$ Copenhagen Economics, Economic Assessment of the Barriers to the Internal Market for Services - Final Report, January 2005.

${ }^{14}$ Commission of the European Communities, Proposal for a Directive of the European Parliament and of the Council on services in the internal market, 5.3.3004, $\operatorname{COM}(2004) 2$ final/3, p. 5.

${ }^{15} \mathrm{COM}(2002) 441$ final, 30.7.2002.

${ }^{16}$ See n. 14 (p. 6).

${ }^{17}$ Commission of the European Communities, An Internal Market Strategy for Services, Communication from the Commission to the Council and the European Parliament, COM(2000) 888 final, 29.12.2000.

${ }^{18}$ See n. 12 (p. 8).

${ }^{19}$ Chancellor Schröder is said to have informed the Commission president about his concerns in this respect; see Frankfurter Allgemeine Zeitung No. 40, 17.2.2005, p. 14.

${ }^{20}$ See n. 14 (p. 9).

${ }^{21}$ Art. 6, see n. 14 .

${ }^{22}$ Art. 9 sec. 1 of the proposed directive.

${ }^{23}$ Art. 40 of the proposed directive.
} 
When the Barroso Commission took office, it first gave the impression that it would further pursue the proposal with the same vigour as its predecessor. The German Chancellor was reported to have tried to influence the president in a meeting in Brussels, with the French president apparently backing the German position. Despite this pressure from some of the old Member States, it came as a surprise when, in early March 2005, the Commission agreed to change the proposal in many relevant aspect with a clear option to water it down ${ }^{24}$. Even if this was no withdrawal in the formal sense, president José Manuel Barroso was reported to have declared the proposal "politically and technically unworkable" and that serious revision was required ${ }^{25}$. The German Commission responsible for enterprise and industry, Günter Verheugen, declared that the Commission had always wanted to avoid its proposal causing "Lohndumping" (wage dumping) ${ }^{26}$, thereby implying that the one under discussion might do exactly this. Even the rule that can be regarded as the cornerstone of the proposal, namely the country of origin principle, was apparently seen as an aspect that needed rewriting ${ }^{27}$. The surprising fact that, apart from the self-evident lack of political agreement on the various elements, the technical workability was also called into question shows very clearly the need for a sober analysis of the regulatory options and their potential or likely outcomes.

\section{The scope of the freedom in the case law of the ECJ and in the treaty}

Promoting the freedom to provide services case-by-case has been a task the ECJ fulfilled long before secondary legislation was recognised as being required to accomplish the internal market in this respect and in order to promote the effective use of this right. On the basis of primary Community law, the Court has established principles that apply to cross-border activities and that remove certain restrictions set up in the national administrations. Considering this ever greater amount of case law on the subject, it is hard to determine clear-cut rules guiding the decisions whether or not a specific factual obstacle violates the fundamental freedoms of the EC treaty ${ }^{28}$. As a general rule, Member States may not force service providers to comply with all conditions required for establishments of their own nationals, as this would deprive the freedom of its practical effectiveness ${ }^{29}$. Article 49 of the Treaty is interpreted as requiring the elimination not only of discriminatory rules, but of any restrictions that render it at least less attractive to provide the services lawfully provided in one Member States also in another one ${ }^{30}$. Therefore, the host Member State - among other things - is not allowed to make the service provider 'subject to an obligation to be entered on the trades register which delays, complicates or renders more onerous the provision of its services ${ }^{31}$. These rules follow the same rationale as the country of origin principle in the proposal by the Commission . If these rules were applied in a strict sense and without exceptions, then the proposal for the

\footnotetext{
${ }^{24}$ The Economist 12.3.2005, p. 36.

${ }^{25}$ Financial Times Europe, 1.3.2005., p. 1.

${ }^{26}$ Interview with Der Spiegel, No. 10/2005, 7.3.2005, p. 30.

${ }^{27}$ Financial Times Europe, 1.3.2005, p. 1.

${ }^{28}$ Claus Dieter Classen, Die Grundfreiheiten im Spannungsfeld von europäischer Marktfreiheit und mitgliedstaatlichen Gestaltungskompetenzen (2004) 416 Europarecht, p. 426.

${ }^{29}$ Case C-76/90, Manfred Säger v Dennemeyer \& Co. Ltd [1991] European Court Reports I-4221, para 12; C165/98, Criminal proceedings against André Mazzoleni and Inter Surveillance Assistance SARL, as the party civilly liable, third parties: Eric Guillaume and Others [2001] European Court Reports I-2189, para. 23.

${ }^{30}$ Case C-76/90, Manfred Säger v Dennemeyer \& Co. Ltd [1991] European Court Reports I-4221, para. 12; C43/93, Raymond Vander Elst v Office des Migrations Internationales [1994] European Court Reports I-3803, para. 14; C-222/95, Société civile immobilière Parodi v Banque H. Albert de Bary et Cie [1997] European Court Reports I-3899, para. 18; C-369/96 and C-376/96, Criminal proceedings against Jean-Claude Arblade and Arblade \& Fils SARL (C-369/96) and Bernard Leloup, Serge Leloup and Sofrage SARL (C-376/96) [1999] European Court Reports I-8453, para. 33; C-58/98, Josef Corsten [2000] European Court Reports I-7919, para. 33. ${ }^{31}$ See n.7 (para. 40).
} 
new directive would, of course, not be needed, as cross-border activities would have to be unrestricted on the basis of the treaty provisions.

The legal situation becomes much more complex, though, when one takes into account the exceptions to this clear-cut rule. The minimum wage is one of the most prominent examples of a rule the Member States are allowed to apply also to service providers established in another Member State if they have employees working, even temporarily, in that country ${ }^{32}$. The Directive concerning the posting of workers ${ }^{33}$ has further elaborated this rule. Nevertheless, an obligatory contribution to the host Member States' social security funds is not justified if no social advantage is conferred on the workers in question ${ }^{34}$. In an early judgement on this freedom, the ECJ decided that 'specific requirements imposed on the person providing the service cannot be considered incompatible with the treaty where they have as their purpose the application of professional rules justified by the general good ${ }^{35}$. Restrictions of the freedom have also been accepted if they serve the purpose of 'guaranteeing the quality of skilled trade work and of protecting those who have commissioned such work" ${ }^{36}$.

The judgements of the ECJ regarding apparent evasions of national rules have been ambiguous $^{37}$. In TV 10 SA v Commissariaat voor de Media, the ECJ ruled that the Member States are allowed to regard service providers established in another Member State as domestic ones, 'since the aim of that measure is to prevent organizations which establish themselves in another Member State from being able, by exercising the freedoms guaranteed by the Treaty, wrongfully to avoid obligations under national law ${ }^{38}$. The same approach was taken with regard to the professional rules of conduct that apply in a Member State when the activities of a service provider are principally directed toward that state although he is established in another one $^{39}$.

More recently, this topic has come to the fore with regard to the company law of the Member States. In Centros,${ }^{40}$ the ECJ had to assess the impact of the freedom to provide services on the registration of companies. The Danish authorities had refused to register a branch of Centros, a private limited company registered in England and Wales, in Denmark on the grounds that the true intention was to establish a principal establishment and to circumvent the national rules, namely the ones regarding the paying-up of minimum capital. The Court ruled that failing to register a branch of a company formed in accordance with the laws of another Member State was contrary to Articles 52 and 58 of the Treaty. What is remarkable with regard to the topic under discussion is the fact that for the case to fall within the scope of Community law the ECJ regarded it as 'immaterial that the company was formed in the first Member State only for the purpose of establishing itself in the second, where its main, or in-

\footnotetext{
${ }^{32}$ Joined cases C-369/96 and C-376/96, Criminal proceedings against Jean-Claude Arblade and Arblade \& Fils SARL (C-369/96) and Bernard Leloup, Serge Leloup and Sofrage SARL (C-376/96) [1999] European Court Reports I-8453, para. 42; C-165/98, Criminal proceedings against André Mazzoleni and Inter Surveillance Assistance SARL, as the party civilly liable, third parties: Eric Guillaume and Others [2001] European Court Reports I-2189, para. 28.

${ }^{33}$ See n. 8 .

${ }^{34}$ Joined cases C-369/96 and C-376/96, Criminal proceedings against Jean-Claude Arblade and Arblade \& Fils SARL (C-369/96) and Bernard Leloup, Serge Leloup and Sofrage SARL (C-376/96) [1999] European Court Reports I-8453, para. 52.

${ }^{35}$ Case 33/74, Johannes Henricus Maria van Binsbergen v Bestuur van de Bedrijfsvereniging voor de Metaalnijverheid [1974] European Court Reports 1299, para. 12.

${ }^{36}$ C-58/98, Josef Corsten [2000] European Court Reports I-7919, para. 38.

${ }^{37}$ See n. 3 (p. 169).

${ }^{38}$ Case C-23/93, TV10 SA v Commissariaat voor de Media [1994] European Court Reports I-04795, para. 21.

${ }^{39}$ Case 33/74, Johannes Henricus Maria van Binsbergen v Bestuur van de Bedrijfsvereniging voor de Metaalnijverheid [1974] European Court Reports 1299, para. 13 et seq.

${ }^{40}$ Case C-212/97, Centros Ltd v Erhvervs- og Selskabsstyrelsen [1999] European Court Reports I-1459.
} 
deed entire, business is to be conducted' ${ }^{41}$. In Inspire Art, ${ }^{42}$ the Court ruled that Member States were not allowed to impose on secondary establishments of companies which were formed in accordance with the law of another Member State conditions such as minimum capital and directors' liability. Thus, the case law could well be described as legalising under European law business strategies that, according to national legal standards, would clearly be repudiated on the grounds of evading binding requirements.

\section{The 'race to the bottom' and specific problems of the Eastern enlargement}

The fears expressed in some of the old Member States are closely linked to the feeling that further market integration might turn into a 'race to the bottom'. One element of this fear were already mentioned in the introductory remarks: since enterprises can take advantage of the cheaper labour costs in other - especially Eastern European - countries, the Member States applying higher standards might have to make some adjustments to their own systems in order to guarantee a high level of employment. What makes the whole problem even more severe is the fact that the new directive is also regarded as a threat for standards in other fields. Apart from fears about what is called 'social dumping', it is also said to be disadvantageous for consumers, standards in agriculture and the environment in general ${ }^{43}$. Some of the leading German experts on fair trading law have expressed their concerns that the country of origin principle might contradict basic prerequisites of effective consumer protection ${ }^{44}$. They complain that service providers have to comply with the laws regarding fair trading in their country of origin. Consequently, advertisement that might be illegal in one Member State might well be legal in the one the service providers is established in. These experts predict that the national authorities will probably not be very inclined to prevent these practices from taking place abroad especially as long as the courts in the other Member State claim jurisdiction in this regard. Another aspect criticised is the delay the country of origin principle causes with regard to legal remedies. While at present the national courts can grant interim injunctions within a very short time, they would, according to this principle, be obliged to apply the laws of the country of origin. It is obvious that no judge can possibly be an expert in the legal orders of all 24 other Member States. As a result, this lack of expertise will most certainly lead to massive delays before legal remedies can become effective.

The discussion about the competitive situation of states and the social standards a country can "afford" is not a new one in the history of European integration. An especially precarious occasion dates back to the negotiations on the Maastricht treaty when the UK on grounds of national sovereignty - which in fact were grounds of the UK's competitive position - refused to accept the so called "Social Charter" and was accordingly granted an opt-out ${ }^{45}$. Still, a close comparison with the case of the Social Charter shows that the situation of the EU after its Eastern enlargement is a very special one: harmonisation on the basis of high standards is hardly an option since it would bring an end to the competitive advantage of countries that undoubtedly have to make up for years of economic malfunctioning. Regrettably, the legitimate hope of sharing the economic capacity the EU as a whole stands for is at least partly connected to this competitive advantage. Consequently, forcing on them the same high standards the

\footnotetext{
${ }^{41}$ Ibid., para 17; see also Case C-167/01, Kamer van Koophandel en Fabrieken voor Amsterdam v Inspire Art Ltd [2003] European Court Reports I-10155, para. 96.

${ }^{42}$ Case C-167/01, Kamer van Koophandel en Fabrieken voor Amsterdam v Inspire Art Ltd [2003] European Court Reports I-10155.

${ }^{43}$ See Süddeutsche Zeitung No. 37, 15.2.2005, p. 24; see also Frankfurter Allgemeine Zeitung, No. 40, 17.2.2005, p. 14.

${ }^{44}$ Frankfurter Allgemeine Zeitung No. 55, 7/3/2005, p. 13.

${ }^{45}$ Deirdre Curtin, The constitutional structure of the Union: A Europe of bits and pieces, CMLR 30 (1993), 17 at 52 et seq.
} 
old Member States have reached would probably eliminate this legitimate hope or would at least decelerate the process of catching up. At the same time, this would call into question the complementary expectation of the old Member States which lies behind the strategy to delay the complete application of fundamental freedoms from applying also to the new ones. It is the expectationthat the accession states will "race to the top" and will have much higher growth rates than the average of the more settled economies are able to generate. In other words, it is not even certain that in the long run the old Member States would actually benefit from measures that in the short term might protect their national standards.

The same situation and especially the same fears regarding a 'race to the bottom' can be found in a number of policy areas. Among the factually most important ones apart from social and employment standards are taxes and the environment. With regard to taxes, the Slovakian model with a flat rate of $19 \%$ for all personal, corporate and sales taxes introduced in 2003 has led to some nervous reactions in European high tax countries while many of the Middle and Eastern European states are planning to follow this example ${ }^{46}$. Here, the topic is discussed under the heading of 'tax dumping' which, as some fear, might erode the tax basis not only in the countries that have already introduced it, but also in those high-tax countries that might feel the pressure to do the same in order to remain an attractive place for investment and production. Especially the net contributors to the EU's budget tend to regard this as simply unfair, as their contribution might finance the funds that could enable the recipients to lower their tax rates and in this way to lure jobs and investment out of the countries that are net contributors. According to this argument, countries are eventually forced to help eroding their own tax basis which is also the basis of their net contributions. With regard to questions of environmental protection, the argument of course has nothing to do with net contributions. Still, since it is difficult to internalise all costs and all the effects polluting plants might cause, countries with high standards are eager to make sure that their policies do not cost them their share of investments and industrial production.

No matter how much evidence there is of the "race to the bottom" really taking place, it can hardly be said that the scenario as such is without foundation. Also, it should be beyond doubt that these mechanisms concern a number of policy areas which cannot be separated from one another. All these policy areas share the feature that harmonisation would be the only completely effective instrument to remove the mechanisms that are thought to generate the "race to the bottom". At the same time, this option would deprive the new Member States of their competitive advantage, which is at the key of hopes to create a Europe with a smaller gap in living conditions. Also, applying EC environmental standards fully to the new accession states already is accepted as being impossible due to the excessive costs this would cause ${ }^{47}$. All in all, therefore, there a good reasons to carry out a sober analysis of the regulatory options and their likely effects on the internal market and on the Member States.

It also has to be borne in mind that the policy areas under discussion have long been identified as representing important aspects of the competitive position of the Member States. One of the consequences of this is that in these areas any harmonisation that might reduce the competitive advantages of the Member States with low taxes or with low standards can only take place in a completely consensual fashion. According to articles $90 \mathrm{ff}$. of the EC treaty, key decision regarding taxes can only be taken by unanimous decision in the Council. In contrast, article $175 \mathrm{sec} .1$ renders article 251 applicable with regard to environmental regulation, thereby opening the path for majority decisions. What is interesting, though, is the fact, that with regard to certain types of environmental regulation - namely ones with a tax character -

\footnotetext{
${ }^{46}$ See The Economist, 5.3.2005, p. 34

${ }^{47}$ See n. 1 (p. 218).
} 
article 175 sec. 2 again demands unanimous decisions. Also, article 176 guarantees the opportunity for Member States to apply higher standards - a rule showing that the Member States do not mind if other states impair their competitive position.

\section{Regulatory options}

The problems associated with the directive on services in the internal market are in many ways typical of the regulatory options the EC is generally faced with in the process of creating a truly internal market. The fact that the Commission has identified the need for such a directive illustrates the obstacles service providers are still faced with in the internal market. Although freedom to provide services is a right that has been guaranteed by the treaty for many decades, there remain both legal and non-legal obstacles. This seems to be a consequence of the fact that even non-discriminatory authorisation schemes hinder foreign service providers almost invariably more than the ones established in the respective countries. Nevertheless, it is difficult to tackle these non-discriminatory schemes with the mechanisms provided by the European legal system. They are manifold and it is often hard to tell how valid the reasons of general interest put forward by the legislatures really are. Therefore, the legitimacy of the Commission's attempt to remove the legal obstacles and to at least ameliorate the non-legal ones should be self-evident. Even if some of the Member States have benefited from the fact that the internal market has been far from being accomplished in the area of services, it is hard for them to argue that these restrictions need to be preserved in order to achieve certain internal policy objectives. Taken this legal view and the fact that on several occasionsthe improved cross-border exchange of services has been described as a job-creating opportunity, the question remains as to how opposition to these plans can be justified in the long run.

Even politicians that are anxious to avoid the negative consequences of the Commission's proposals generally stop short of demanding that the standards in the country of provision should be the only relevant ones. Rather, one solution is seen to be another delay before the freedom takes full effect. Another option lies in exceptions for certain sector - namely building and health - where competition from cheaper providers might be particularly strong ${ }^{48}$. Again, this solution expresses the hope that the gap between the countries with high labour costs and the ones with lower costs might increasingly close under the influence of European integration ${ }^{49}$. Unfortunately, this might lead to a situation in which possible negative effects are not prevented, but merely postponed.

Apart from these two solutions, there is another one that for a long time was the dominant approach to further economic integration. A German social democratic MEP was quoted as favouring European harmonisation since letting 25 different rules apply contradicted the "idea" of the community ${ }^{50}$. Of course, following this suggestion would mean a clear deviation from the present-day consensus that harmonisation, due to its inefficiency and its bureaucratic consequences, should be the option of last resort. The Commission has made it clear that it has no intention of harmonising the rules of service provision in the Member States and it discredits this option as over-regulation and standardisation of the specific features of national systems ${ }^{51}$. With regard to services, the fear is that even minimum standards would impose regulation on countries that have opted for rather liberal regimes ${ }^{52}$. Since the decision of the ECJ in

\footnotetext{
${ }^{48}$ See Frankfurter Allgemeine Zeitung, No. 40, 17.2.2005, p. 14.

${ }^{49}$ See n. 2 (p. 104).

${ }^{50}$ Frankfurter Allgemeine Zeitung, No. 40, 1.2.2005, p. 14.

${ }^{51}$ See n. 14 (p. 8).

${ }^{52}$ The Economist 12.3.2005, p. 36 .
} 
the case Cassis de Dijon ${ }^{53}$, the principle of mutual recognition has generally been acknowledged to be the most efficient way to create an internal market. Still, harmonisation might mean different things. If the standards set by EC legislation are low, then the main concern is the completion of the internal market. If the standards are high, then policy integration dominates the elements of market integration ${ }^{54}$. This thought paves the way for a compromise where some standards are guaranteed by Community law, while the main mechanism remains mutual recognition.

If one takes seriously the legal obligation and the political commitment to create an internal market also for services, then there is generally no legitimate role for obstacles set up by national legislation. Nevertheless, it would not be justified to leave national employees and the people working for service operators across borders unprotected. Considering the problems regarding the "race to the bottom", the solution can certainly be found in legislation at the European level alone. Therefore, the competence for some harmonisation does not stem from any special competence for social affairs, but rather from the need to find an appropriate environment for the internal market that will lead to a reduction also in the factual obstacles. To this effect, the EC has already produced remarkable legislation. In December 1996 the Directive 96/71/EC concerning the posting of workers in the framework of the provisions of services was passed ${ }^{55}$. Many hopes for an orderly development are linked to this directive ${ }^{56}$ because it offers the mechanisms that should help to protect social standards under the described circumstances. Recital 13 explicitly states that 'the laws of the Member States must be coordinated in order to lay down a nucleus of mandatory rules for minimum protection to be observed in the host country by employers who post workers to perform temporary work'. Recital 14 demands 'a "hard core" of clearly defined protective rules'. Consequently, Article 3 establishes an obligation on the side of the host country to lay down rules on maximum work periods, minimum paid annual holidays, minimum rates of pay, health, safety and hygiene at work, and a variety of other rules with regard to the protection of workers.

\section{Future Perspectives}

In many ways, the old, the new, and future new Member States are united in the hope that the gap regarding the economic and social standards will close. Under the conditions of the internal market, lower standards might mean not only hardship for the people that are subject to them, but also a severe threat for higher standards in the other countries. Fears regarding the 'race to the bottom' might be exaggerated. Nevertheless, there can be no doubt that mechanisms are in place that might lead to a sort of decentralised harmonisation on a level far below the ones achieved in the old Member States. This is not to imply that all national particularities regarding certain groups of services should be preserved. Achieving a smooth functioning of the internal market - apart from being a concept that is generally considered to be worth pursuing from an economic point of view - has also become a legal obligation. Therefore, it is undoubtedly a legitimate approach to demand some sort of competitiveness from the national systems - a competitiveness that has to be tested on the internal market. Not everything that cannot survive in this market has a right to be protected from competition. Market access and taking up the challenges from foreign competitors has been the idea that formed the basis of European integration and its economic model. Therefore, the question remains as to what are the minimum standards both to ensure the further development of the internal market and at

\footnotetext{
${ }^{53}$ Case C-120/78, Rewe v. Bundesmonopolverwaltung für Branntwein, [1979] European Court Reports 649.

${ }^{54}$ René Barents, The internal market unlimited: Some observations on the legal basis of Community legislation (1993) 30/1 CMLR, 85 (101).

${ }^{55}$ See n. 8 .

${ }^{56}$ See for example interview with Commissioner Verheugen, Der Spiegel, No. 10/2005, 7.3.2005, p. 30.
} 
the same time to prevent practical problems that might harm the acceptance of further integration.

\section{1) Mutual recognition of standards and qualifications}

There is no doubt that mutual recognition of standards and qualifications has to be the starting point of any further improvement of the functioning of the internal market. The argument that is generally applicable in this discussion is the apparent lack of efficiency and the bureaucratic burden these rules cause. Directive 1999/42/EC establishing a mechanism for the recognition of qualifications ${ }^{57}$ offers a perfect example of mutual recognition applied in a way that takes into account some of the above-mentioned concerns. According to Article 3 (1) Member States are not allowed to refuse a work permit on the same grounds that apply to their own nationals. Instead, they have to compare the knowledge and skills of the nationals of the other Member States and - in case of a lack of compatibility - to grant an adaptation period or an aptitude test before.

The accession of the 10 new Member States on May $1^{\text {st }} 2004$ has generated a new argument. Harmonisation of standards at the levels the old Member States have achieved would cause costs in production that would destroy the competitive advantage the new Member States have. This would not only reduce their legitimate hopes of catching up with the old Member States. The old Member States certainly also hope to see the gap to the other countries in the Union close since this could also reduce the fears regarding the 'race to the bottom'. Mutual recognition translated into the wording of services regulation induces the application of the country of origin principle. Possible negative effects in the implementation of this principle can only be prevented by additional regulation that modifies the principle without removing its rationale altogether.

\section{2) Minimum harmonisation at European level}

Minimum harmonisation on the one hand and maximum harmonisation on the other hand have become some sort of legislative ideal types that can be chosen depending on the agreement between the Member States ${ }^{58}$. Which minimum social standards should apply in crossborder activities is clearly a matter to be solved by EC legislation. The problems that have been described offer sufficient reasons for securing an acceptable standard of worker and consumer protection at the EC level. Any implementation of the country of origin principle requires a sufficient amount of mutual trust in the standards applicable in the other countries. If this trust is not in place, new factual disruptions of the functioning of the internal market might be a result. In particular, there will always be a strong aspiration on the part of the Member States to protect their standards even by doubtful means. A certain amount of harmonisation has been a typical compensation in directives that establish the country of origin principle $^{59}$. Consequently, if one wants the freedom to provide services to become a reality, then one might have to accept that some form of harmonisation may be the price one has to pay. The above mentioned directive concerning the posting of workers offers an important

\footnotetext{
${ }^{57}$ Directive 1999/42/EC of the European Parliament and of the Council of 7 June 1999 establishing a mechanism for the recognition of qualifications in respect of the professional activities covered by the Directives on liberalisation and transitional measures and supplementing the general systems for the recognition of qualifications [1999] Official Journal L 201, p. 77 - 93.

${ }^{58}$ See Peter Rott, Minimum Harmonization for the Completion of the Internal Market? The Example of Consumer Sales Law (2003) 40 CMLR, 1107 at $1108 \mathrm{f}$.

${ }^{59}$ Jürgen Basedow, Dienstleistungsrichtlinie, Herkunftslandprinzip und Internationales Privatrecht (2004) Europäische Zeitschrift für Wirtschaftsrecht, p. 423.
} 
element of this strategy. In the face of this directive many of the fears regarding social dumping seem exaggerated, if not completely unfounded. Apart from the fact that minimum standards are of course far lower than the ones achieved in many of the old Member States, it is mainly the problem of efficient control mechanisms that gives cause for concern.

\section{3) Implementation, judicial system and administrative co-operation}

The ECJ has made it clear that restrictions of the freedom to provide services cannot be justified if the reasons for them are of a purely administrative nature ${ }^{60}$. Authorisation procedures that apply in the host Member State 'should neither delay nor complicate exercise of the right of persons established in another Member State to provide their services on the territory of the first State ${ }^{61}$. Still, even this legal guarantee does not seem to have abolished all factual obstacles that exist because Member States follow their own system of authorisation and administration. In this respect, the Commission proposal has paved the way for a sober analysis of the problems that stem not from the regulatory approach as such, but from the implementation of the rules. Nevertheless, it seems doubtful whether the Commission proposal can be the final word in this respect. Of course, the co-operation between the various administrations as well as the permanent evaluation of the mechanisms in place as envisaged in the proposal are important aspects of any concept for improving the elements of the internal market. The problem is that these rather far-reaching proposals might be good enough to remove obstacles that hinder the provision of services across borders. They certainly are not sufficient to prevent practices that are clearly illegal from taking place. Especially in the administration of worker protection, an organised system for co-operation and exchanges of information is crucial ${ }^{62}$. If one also takes into account the above mentioned problems of access to efficient legal remedies, these administrative and judicial questions might well prove to be at the core of the endeavour of finding acceptable solutions within the existing and indeed any new legal framework.

\footnotetext{
${ }^{60}$ See n.36, para. 42; See n.34, para. 37.

${ }^{61}$ See n.36, para. 47.

${ }^{62}$ See n. 34, para. 79.
} 